\title{
EVALUATION OF THE NEUROPROTECTIVE POTENTIAL IN MPP+-INDUCED NEURODEGENERATION OF NEW HETEROCYCLIC COMPOUNDS BASED ON PYRAZOLOPYRIDINE SCAFFOLD
}

Mohammed Loubidi 1,2, Jabrane Jouha 2,3, Zahira Tber ${ }^{2}$, Güliz Armagan ${ }^{4}$

BP 146, 28800, Mohammedia, Morocco (2) Institut de Chimie Organique et Analytique (ICOA), Université d'Orléans, BP 6759, 45067 Orléans cedex 2

France; (3) School of Chemistry and Chemical Engineering, Hunan University, BP, 410082, Changsha, China (4) Department of Biochemistry, Faculty of Pharmacy, Ege University, 35100 Bornova, Izmir, Turkey.

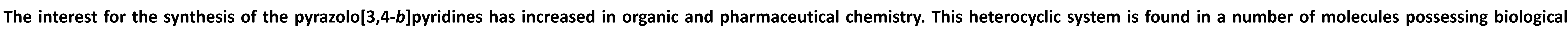

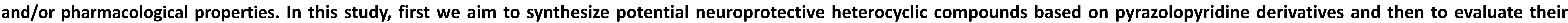

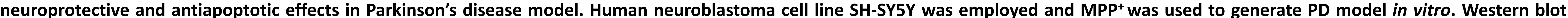
analysis was made to assess the apoptotic effect of $\mathrm{MPP}^{+}$on SH-SY5Y cells and the potential neuroprotective effects of the synthesized compounds.

\section{1 - Synthetic strategies / Pharmacomodulations

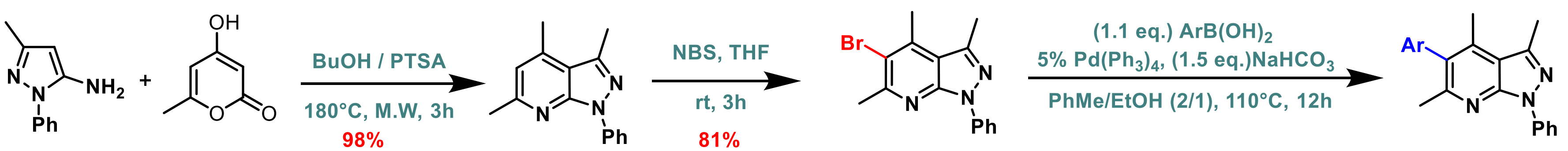

$\square$ Scope of Suzuki-Miyaura cross coupling of $\underline{4}$

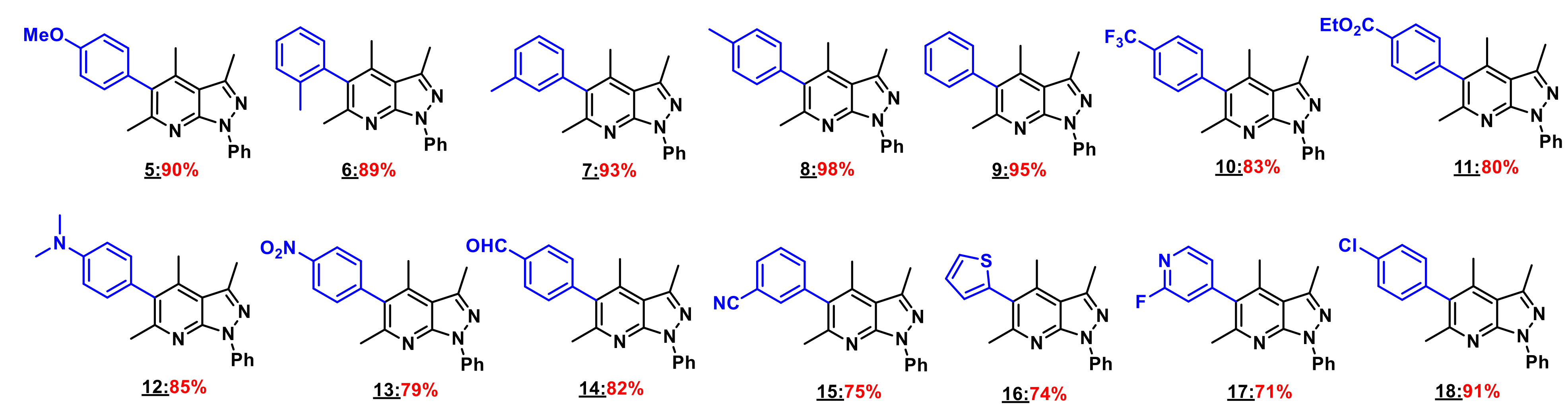

\section{2 - Biological studies}

\section{Cell viability studies}

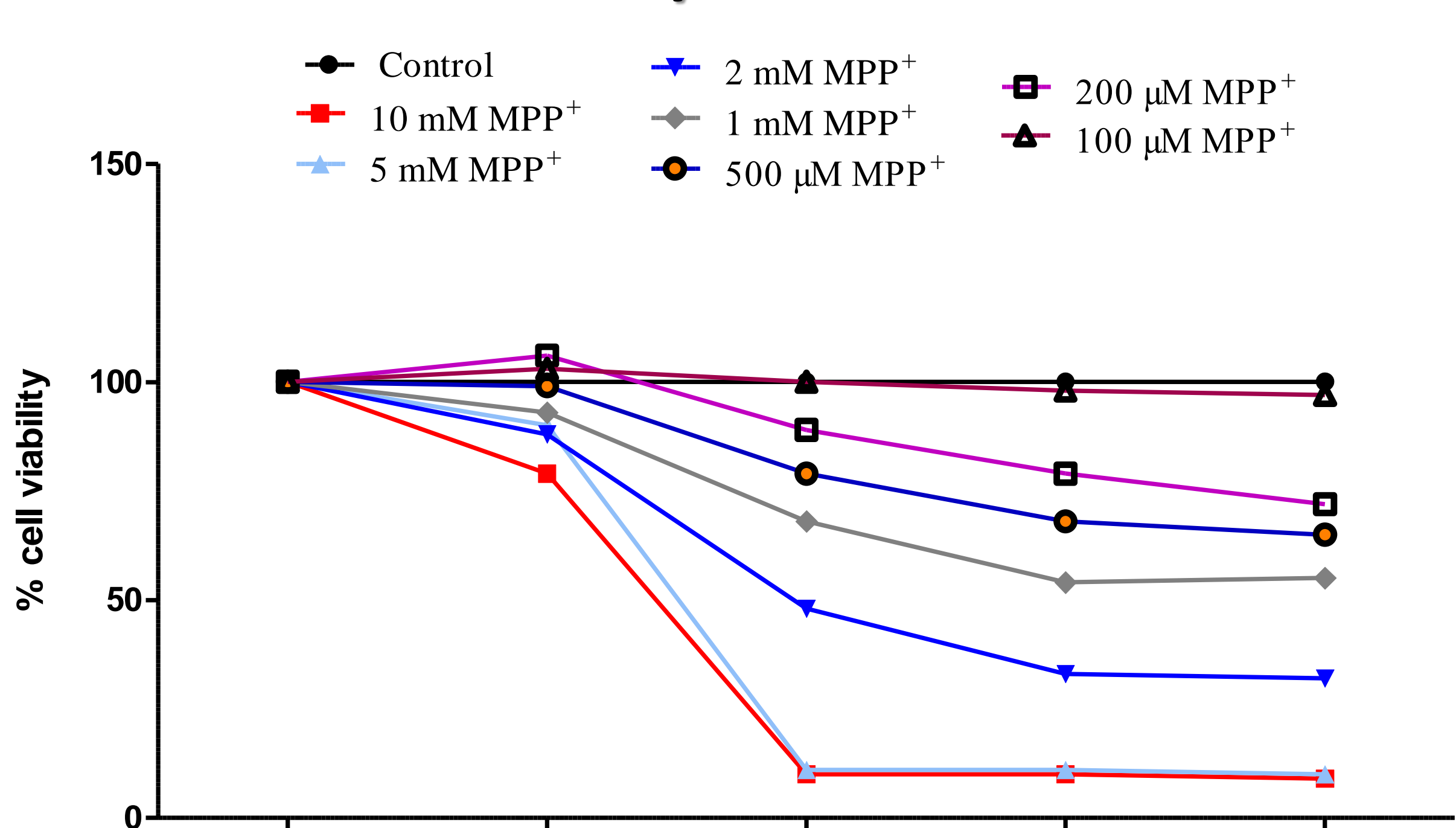

Fig .1. Evaluation of cell viability of SHSY5Y cells exposed to various concentrations $(0.1-10 \mathrm{mM})$ of $\mathrm{MPP}^{+}$at indicated times. Cells were treated for 12 , 24, 36 and $48 \mathrm{~h}$ at $37^{\circ} \mathrm{C}$. Data represent the mean + SD of at least six independent experiments in triplicate and are expressed as percentage of control cells.

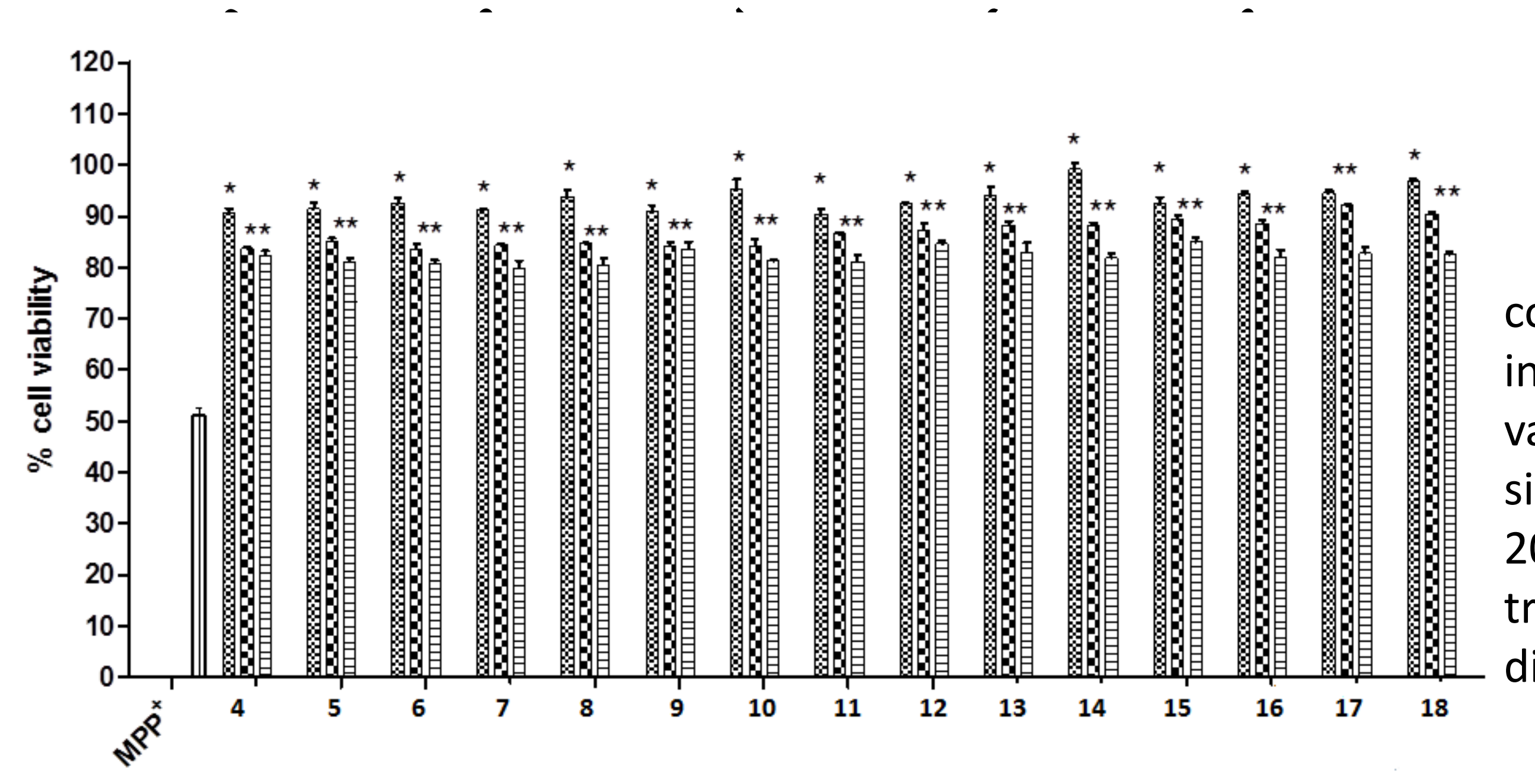

Fig.2. Effects of newly synthesized compounds on cell viability in MPP induced dopaminergic cell death. All values are means $\pm \operatorname{SDs}(n=5) . * 0<0.05$ significant difference from MPP ${ }^{+}$and 10 or $20 \mu \mathrm{M}$ concentrations of compound treatments. $\quad * * \quad p<0.05 \quad$ significant difference from MPP+'-treated cells..

$$
5 \mu \mathrm{MM} 10 \mu \mathrm{MM} \quad \square 20 \mu \mathrm{MM} \text { 四 } 2 \mathrm{mMMPP}+
$$

\begin{tabular}{|c|c|c|c|}
\hline Compound & \% Neuroprotection & Compound & \% Neuroprotection \\
\hline 4 & $*$ at 10 and $20 \mu \mathrm{M} / * *$ at $5 \mu \mathrm{M}$ & 11 & ${ }^{*}$ at 10 and $20 \mu \mathrm{M} / * *$ at $5 \mu \mathrm{M}$ \\
\hline 5 & ${ }^{*}$ at 10 and $20 \mu \mathrm{M} / * *$ at $5 \mu \mathrm{M}$ & 12 & ${ }^{*}$ at 10 and $20 \mu \mathrm{M} / * *$ at $5 \mu \mathrm{M}$ \\
\hline 6 & ${ }^{*}$ at 10 and $20 \mu \mathrm{M} / * *$ at $5 \mu \mathrm{M}$ & 13 & ${ }^{*}$ at 10 and $20 \mu \mathrm{M} /{ }^{* *}$ at $5 \mu \mathrm{M}$ \\
\hline 7 & ${ }^{*}$ at 10 and $20 \mu \mathrm{M} /{ }^{* *}$ at $5 \mu \mathrm{M}$ & 14 & ${ }^{*}$ at 10 and $20 \mu \mathrm{M} /{ }^{* *}$ at $5 \mu \mathrm{M}$ \\
\hline 8 & $*$ at 10 and $20 \mu \mathrm{M} / * *$ at $5 \mu \mathrm{M}$ & 15 & $*$ at 10 and $20 \mu \mathrm{M} / * *$ at $5 \mu \mathrm{M}$ \\
\hline 9 & $*$ at 10 and $20 \mu \mathrm{M} / * *$ at $5 \mu \mathrm{M}$ & 16 & $*$ at 10 and $20 \mu \mathrm{M} / * *$ at $5 \mu \mathrm{M}$ \\
\hline 10 & ${ }^{*}$ at 10 and $20 \mu \mathrm{M}^{* *}$ at $5 \mu \mathrm{M}$ & 17 & ${ }^{* *}$ at 5 and $10 \mu \mathrm{M} /{ }^{*}$ at $20 \mu \mathrm{M}$ \\
\hline & & 18 & ${ }^{* *}$ at 5 and $10 \mu \mathrm{M} /{ }^{*}$ at $20 \mu \mathrm{M}$ \\
\hline
\end{tabular}

The percentage of neuroprotection-induced by compounds against MPP+-induced neurotoxicity in SH-SY5Y cells. ${ }^{*}$ Neuroprotection is between $10 \%-20 \%$. ${ }^{* *}$ Neuroprotection is between $20 \%-30 \%$.

\section{$\square$ Protein analysis}

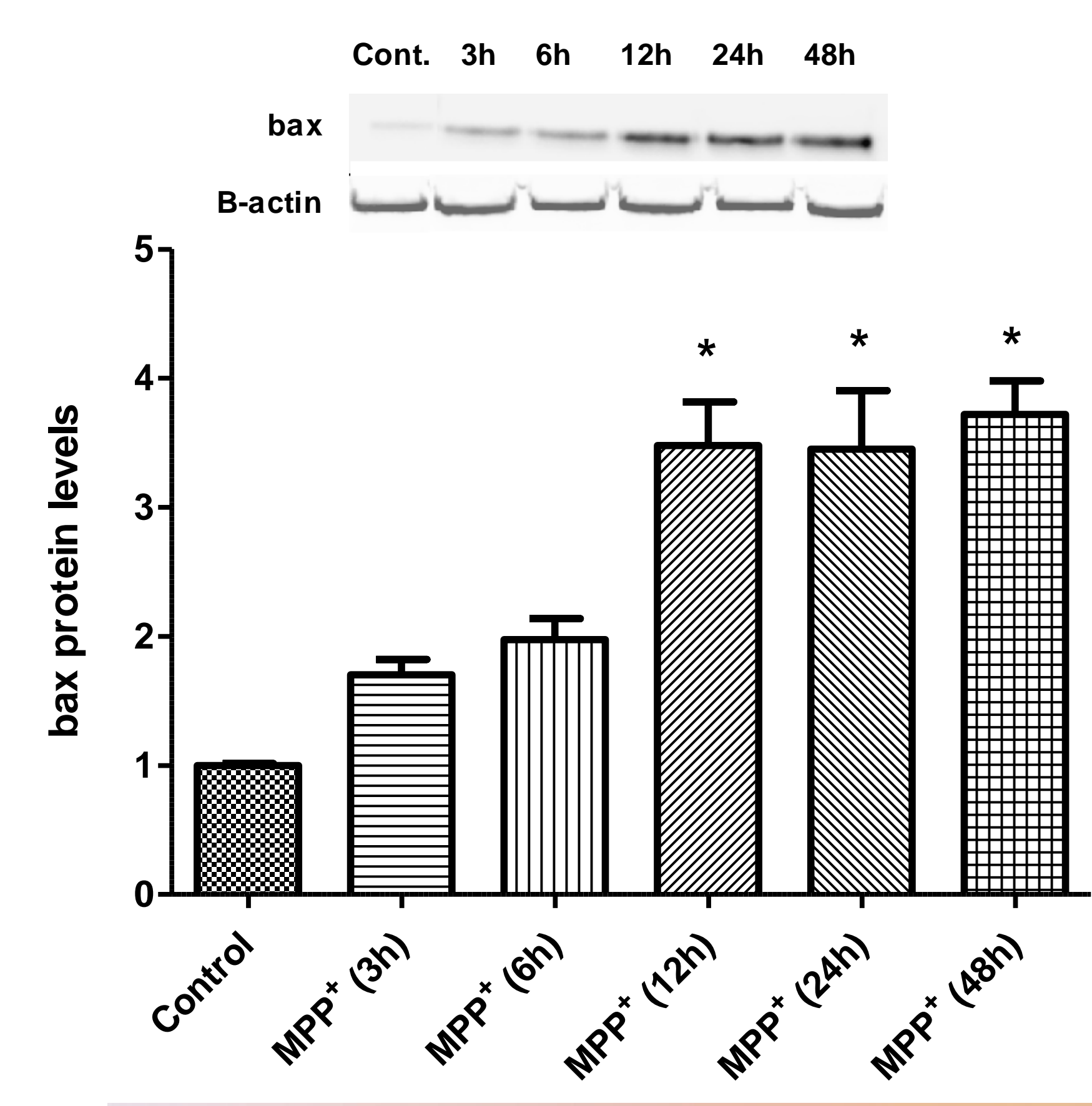

Fig .3. The changes in proapoptotic bax protein levels following MPP+ treatments for 3, 6, 12, 24, $48 \mathrm{~h}$ in $\mathrm{SH}-\mathrm{SY} 5 \mathrm{Y}$ cells. ${ }^{*} \mathrm{p} \leq 0.05$ significant difference from control group and 3 or 6 hours MPP+- treated cells
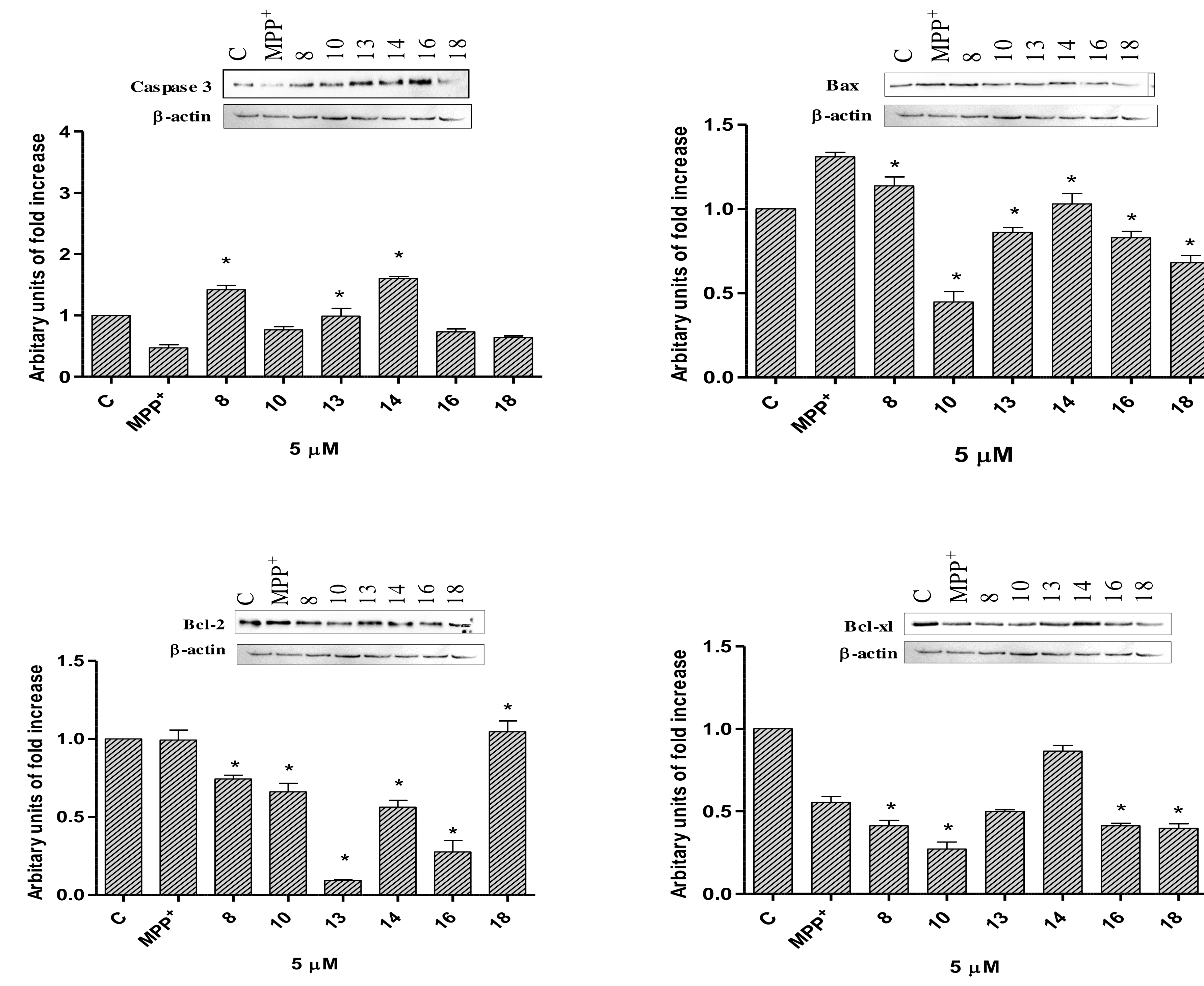

Fig . 4. The changes in bax, caspase-3, BCl-2 and Bcl-xl protein levels following $5 \mu \mathrm{M} \mathbf{8}, \mathbf{1 0}, \mathbf{1 3}$ 14,16 or 18 against $2 \mathrm{mM}$ MPP+-induced apoptosis. Representative Western blots showing protein expression of protein levels following treatments. Graphs indicate the relative densitometric values of indicated proteins. Quantification of protein product was performed by densitometric scanning. Data are normalized by using the $\beta$-actin signal and expressed as arbitrary densitometric units. Values are means $\pm S D ; n=3$ in each group.. ${ }^{*} p<0.05$ significant difference from MPP+treated cells.
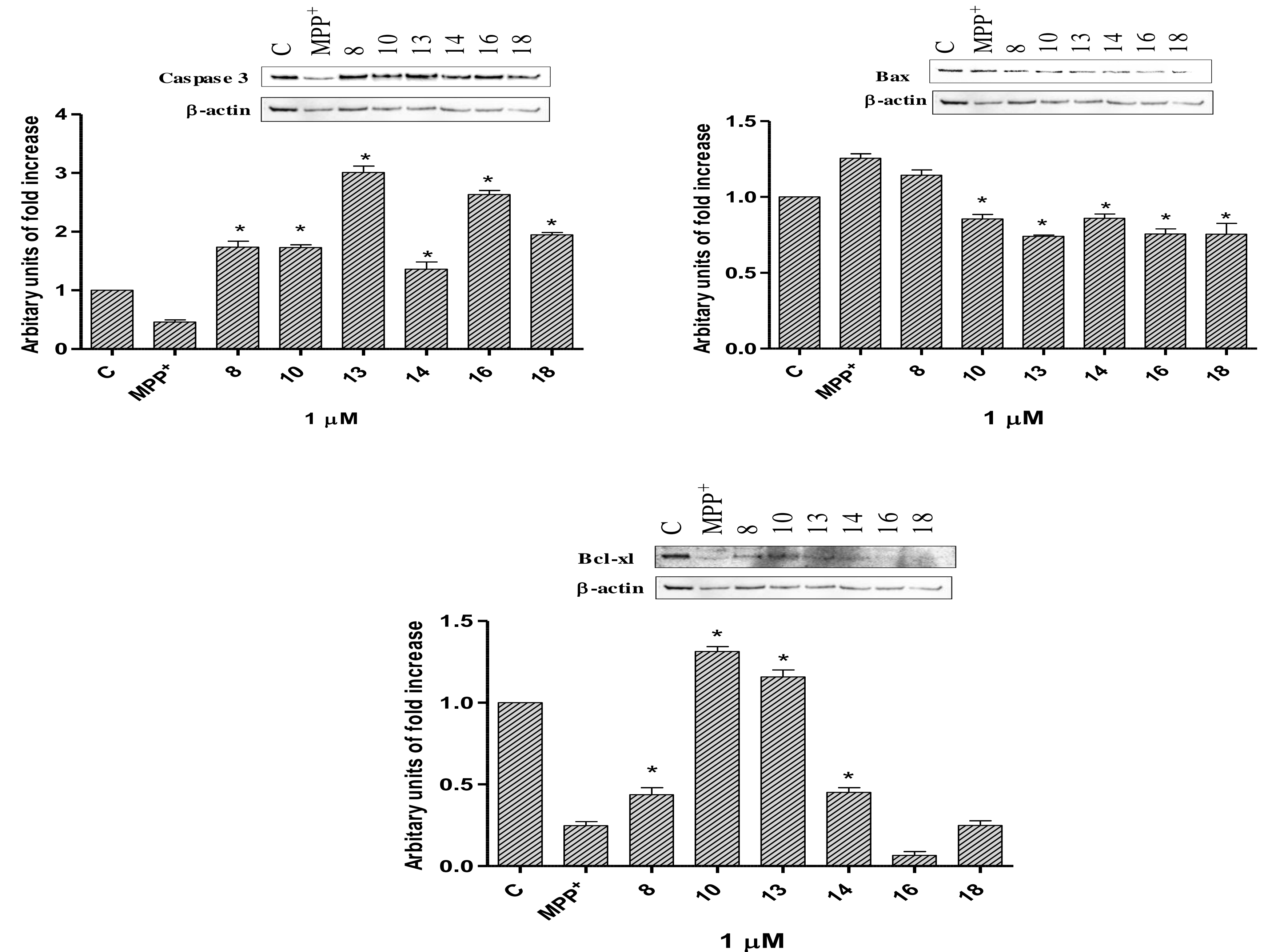

Fig .5. The changes in bax, caspase-3 and Bcl-xl protein levels following $1 \mu \mathrm{M} \mathrm{8,} \mathrm{10,13,14,16}$ or 18 against $2 \mathrm{mM} \mathrm{MPP+-induced} \mathrm{apoptosis.} \mathrm{Representative} \mathrm{Western} \mathrm{blots} \mathrm{showing} \mathrm{protein}$ expression of protein levels following treatments. Graphs indicate the relative densitometric values of indicated proteins. Quantification of protein product was performed by densitometric scanning. Data are normalized by using the $\beta$-actin signal and expressed as arbitry densitometric units. Values are means \pm SD; $n=3$ in each group. * $p<0.05$ significant difference from MPP. treated cells.

\section{3-Conclusion / References}

In conclusion, our results provide an evidence that these heterocyclic compounds based on pyrazolopyridine scaffold have a role on dopaminergic neuroprotection. The neuroprotection of the compounds against MPP+-induced apoptosis may be associated with the regulation of pro- and anti-apoptotic proteins, oxidative stress and downregulation of caspase-3 activation. According to our results, we suggest that these compounds, particularly most active ones, can be used for potential novel therapies in the treatment of Parkinson's disease.

[1] J. Jouha, M. Loubidi, J. Bouali, S. Hamri, A. Hafid, F. Suzenet, G. Guillaumet, T. DagCı, M. Khouili, F. Aydın, L. Saso, G. Armagan, Eur. J. Med. Chem. 129 (2017) 41-52. [2] S. Fadel, F. Suzenet, A. Hafid, E.M. Rakib, M. Khouili, M.D. Pujol, G. Guillaumet, J. Heterocycles. Chem. 46 (2009) 1177-1184.

[3]R.L. Jayaraj, K. Tamilselvam, T. Manivasagam, N. Elangovan, J. Mol. Neurosci. 51 (2013) 863-870 